\title{
PERANAN KELOMPOK TANI "TENGGANG RASA" TERHADAP PENGEMBANGAN TANAMAN KAKAO DI DESA INOMUNGA, KECAMATAN KAIDIPANG, KABUPATEN BOLAANG MONGONDOW UTARA
}

\author{
Margaretha Impal \\ Benu Olfie L. S. \\ Vicky R. B. Moniaga
}

\begin{abstract}
ABSRACT
This study aims to describe the role of Farmers Group "Tenggang Rasa" to the development of cocoa plants in the village of Inomunga, Kaidipang Sub-district, Utara Bolaang Mongondow District, North Sulawesi Province. The study lasted for 3 (three) months from January to March 2017 in Inomunga Village, Kaidipang Sub-district, Bolaang Mongondow Utara District. The data used were primary data collected through interviews with all members of farmer group "Tenggang Rasa" which amounted to 15 people as respondents. Secondary data were obtained from the Agricultural Office, the Inomunga Village Office and the District Office in Bolaang Mongondow Utara. The analytical method used is descriptive through Likert Scale and presented in tabular form. The results showed that "Tenggang Rasa" Farmer Group in Inomunga Village has a very important role as learning class, cooperation vehicle and production unit to develop cocoa plant by getting index of role which belong to high category that is 82,85 percent. With the existence of farmer groups, farmers are very helpful in overcoming their problems to get solution for the development of cocoa plants.
\end{abstract}

Keywords: role, farmer groups, "Tenggang Rasa", Cocoa crops, Inomunga Village, North Bolaang Mongondow District

\begin{abstract}
ABSTRAK
Penelitian ini bertujuan untuk mendeskripsikan peranan Kelompok Tani "Tenggang Rasa" terhadap pengembangan tanaman kakao di Desa Inomunga, Kecamatan Kaidipang, Kabupaten Bolaang Mongondow Utara. Penelitian berlangsung selama 3 (tiga) bulan mulai dari bulan Januari sampai Maret 2017. Data yang digunakan yaitu data primer yang dikumpulkan melalui wawancara pada semua anggota kelompok tani "Tenggang Rasa" yang berjumlah 15 orang sebagai responden. Data sekunder diperoleh dari kantor Dinas Pertanian, Kantor Desa Inomunga dan Kantor Kecamatan di Bolaang Mongondow Utara. Metode analisis yang digunakan yaitu secara deskriptif melalui Skala Likert dan disajikan dalam bentuk tabel. Hasil penelitian menunjukkan bahwa Kelompok Tani Tenggang Rasa di Desa Inomunga Kecamatan Kaidipang mempunyai peranan yang sangat penting sebagai kelas belajar, wahana kerjasama dan unit produksi terhadap pengembangan tanaman kakao dengan mendapatkan indeks peranan yang tergolong kategori tinggi yaitu 82,85 persen. Dengan adanya kelompok tani, petani sangat terbantu dalam mengatasi permasalahan yang mereka hadapi, mendapatkan solusi untuk pengembangan tanaman kakao.
\end{abstract}

Kata kunci: Peranan, Kelompok Tani, “Tenggang Rasa”, Tanaman Kakao, Desa Inomunga, Kabupaten Bolaang Mongondow Utara 


\section{PENDAHULUAN}

\section{Latar Belakang}

Indonesia dikenal oleh masyarakat dunia sebagai negara agraris. Sebutan demikian itu antara lain dikaitkan dengan mata pencaharian pokok sebagian besar rakyat Indonesia dalam bidang pertanian (Bustanul, 2015). Komoditi yang diusahakan dalam perkebunan di Indonesia adalah kakao (Tuhana, 2014). Kakao merupakan salah satu komoditas hasil perkebunan dan banyak diusahakan dalam sistem perkebunan di Indonesia. Indonesia sebagai produsen kakao dunia berhasil memproduksi kakao yang berkualitas tinggi sehingga banyak dibeli oleh negara lain. Pengembangan usaha kakao ke depan secara global diarahkan sedemikian rupa agar dapat mewujudkan terciptanya agribisnis kakao yang efisien dan efektif. Dengan demikian diharapkan terjadi peningkatan pendapatan petani, khususnya petani kakao di Indonesia. Peran penting kakao dalam agribisnis tidak terlepas dari pemanfaatan kakao khususnya untuk konsumsi sehingga kakao diperdagangkan secara internasional sebagai komoditas agribisnis penting saat ini (Tuhana, 2014). Menurut Marru dan Sipayung (2015), bahwa Indonesia termasuk negara penghasil kakao terbesar kedua setelah Pantai Gading.

Dalam proses pengembangan kakao pemerintah membentuk kelembagaan yaitu kelompok tani. Dengan adanya kelompok tani, maka akan mempermudah petani untuk meningkatkan produktivitas tanaman kakao. Salah satu peran penting yang perlu diandalkan dalam pengembangan di bidang pertanian adalah melalui aktivitas kelompok tani. Karena dalam melaksanakan kegiatan pertanian tanpa adanya organisasi maka pelaksanaan kegiatan pertanian akan menghadapi kendala (Wuysang, 2015). Oleh karena itu organisasi yang diaplikasikan lewat kelompok tani menjadi model pengembangan usaha tani Tujuan dibentuknya kelompok tani adalah untuk lebih meningkatkan dan mengembangkan kemampuan petani dan keluarganya sebagai subjek pembangunan pertanian melalui pendekatan kelompok agar lebih berperan dalam pembangunan. Kelompok tani merupakan suatu bentuk perkumpulan petani yang berfungsi sebagai media penyuluhan yang diharapkan lebih terarah dalam perubahan aktivitas usahatani yang lebih baik lagi (Iqbal,
2014). Kelompok tani memiliki peran yang sangat penting dalam upaya pengembangan tanaman kakao untuk memperoleh produksi yang maksimal. Dengan adanya kelompok tani, para petani dapat bersama-sama memecahkan permasalahan yang antara lain berupa pemenuhan sarana produksi pertanian, teknis produksi dan pemasaran hasil. Salah satu daerah di Provinsi Sulawesi Utara yang memproduksi kakao dan mendapatkan Program Gerakan Kakao Nasional (Gernas) adalah Desa Inomunga Kecamatan Kaidipang Kabupaten Bolaang Mongondow Utara. Di Desa Inomunga, kakao merupakan potensi yang terbanyak kedua dari kelapa. Desa Inomunga memiliki luas lahan tanaman kakao sebesar 22 ha. Dalam upaya pengembangam tanaman kakao maka pemerintah dan masyarakat petani membentuk satu kelompok tani yang bernama "Kelompok Tani Tenggang Rasa". Kolompok ini berdiri sejak tahun 2011 yang pada awalnya memiliki nama "Pomomuntula" dengan beberapa komoditi usaha perkebunan, pertanian, pangan dan hortikultura.

Pada waktu program Gernas masuk Ke Bolaang Mongondow Utara, sesuai dengan kesepakatan bersama kelompok mengganti nama kelompok tani "Tenggang Rasa" dengan satu komoditi perkebunan yaitu kakao. Dengan dibentuk Kelompok Tani "Tenggang Rasa" maka petani juga dapat mempermudah pemerintah untuk mengembangkan tanaman kakao. Tetapi, Kelompok Tani "Tenggang Rasa" belum memaksimalkan kelompok. Banyak kelompok tani yang dibentuk, tetapi tidak melakukan peran sebagaimana mestinya. Ada yang hanya mengambil untung dari program pemerintah yaitu program Gernas misalnya mereka membentuk kelompok hanya ingin mendapatkan dana. Setelah dana didapatkan, kelompok tidak melakukan kerja sama, dalam melakukan pemeliharaan/perawatan tanaman kakao. Padahal kerja sama kelompok sangat diperlukan untuk peningkatan produksi maupun pendapatan dari petani tersebut. Kelompok juga memiliki aktivitas lain misalnya selain berternak dan ada pula yang menjadi buruh bangunan. Sehingga, kurang melakukan pertemuan kelompok dan ini membuat kelompok kurang optimal dalam pengembangan tanaman kakao. Hal ini yang menjadi latar belakang meneliti kelompok tani "Tenggang 
Rasa". Kelompok Tani "Tenggang Rasa" memiliki peran sangat penting dalam pengembangan tanaman kakao agar supaya memperoleh produksi yang maksimal sesuai harapan dari anggota kelompok.

\section{Perumusan Masalah}

Berdasarkan latar belakang yang telah dikemukakan maka perumusan masalah yaitu: Bagaimana peranan Kelompok Tani "Tenggang Rasa" terhadap pengembangan tanaman kakao di Desa Inomunga Kecamatan Kaidipang Kabupaten Bolaang Mongondow Utara?

\section{Tujuan Penelitian}

Penelitian ini bertujuan untuk mendeskripsikan peranan Kelompok Tani "Tenggang Rasa" terhadap pengembangan tanaman kakao di Desa Inomunga Kecamatan Kaidipang Kabupaten Bolaang Mongondow Utara.

\section{Manfaat Penelitian}

1. Sebagai bahan informasi untuk Kelompok Tani "Tenggang Rasa" dan masyarakat Kecamatan Kaidipang dalam proses pengembangan tanaman kakao di Kabupaten Bolaang Mongondow Utara.

2. Sebagai bahan informasi bagi pemerintah Desa Inomunga Kecamatan Kaidipang, dan

3. Sebagai bahan kajian bagi peneliti lain yang mau melanjutkan penelitian tentang pengembangan tanaman kakao.

\section{METODOLOGI PENELITIAN}

\section{Waktu dan Tempat Penelitian}

Penelitian ini dilakukan selama 3 (tiga) bulan yaitu dari bulan Januari sampai dengan Maret 2017. Lokasi penelitian di Desa Inomunga Kecamatan Kaidipang Kabupaten Bolaang Mongondow Utara.

\section{Metode Pengumpulan Data}

Penelitian ini menggunakan data primer dan data sekunder. Data primer diperoleh dari wawancara langsung pada anggota kelompok tani "Tenggang Rasa" mengenai peran yang dilakukan kelompok tani dalam upaya pengembangan tanaman kakao dengan menggunakan daftar pertanyaan yang telah disiapkan berupa kuisioner. Data sekunder diperoleh dari kantor Pemerintah Desa dan Kecamatan serta Dinas Pertanian Kabupaten Bolaang Mongondow Utara.

\section{Metode Pengambilan Sampel}

Populasi dalam penelitian ini yaitu semua anggota kelompok tani "Tenggang Rasa" yang berjumlah 15 responden.

\section{Konsep Pengukuran Variabel}

Adapun variabel yang diteliti adalah :

1. Peran Kelompok Tani "Tenggang Rasa" sebagai kelas belajar:

a. Saling tukar-menukar pikiran anggota dengan yang lain

b. Pelaksanaan penyuluhan yang dilakukan Penyuluh, Petugas Pendamping Kakao untuk pengembangan tanaman kakao

c. Ikut serta anggota kelompok dalam penyuluhan

d. Kelompok mempraktekkan hasil penyuluhan yang dilakukan.

2. Peran Kelompok Tani "Tenggang Rasa" sebagai wahana kerja sama:

a. Kelompok bersama-sama mengatasi masalah yang terjadi dalam penanggulangan hama/penyakit pada kakao.

b. Anggota kelompok berkoordinasi dengan pengurus kelompok

c. Kelompok melakukan kerja sama untuk pengembangan tanaman kakao baik antar anggota kelompok atau dengan kelompok tani yang lain.

d. Kelompok melakukan pertemuan berkala untuk membahas pengembangan tanaman kakao terkait dengan teknologi maupun sarana produksi.

e. Kelompok mengadakan pertemuan untuk membahas tujuan kelompok dan anggaran dasar/anggaran dasar rumah tangga.

f. Kelompok melakukan pembagian tugas berdasarkan penetapan kegiatan yang akan dikerjasamakan baik antar anggota maupun dengan pihak lain.

3. Peran Kelompok Tani "Tenggang Rasa" sebagai unit produksi:

a. Kelompok melakukan kegiatan seperti melaksanakan survei identifikasi kebutuhan pasar.

b. Kelompok menghitung hasil/jumlah produski kakao. 
c. Peningkatan produksi dan lahan produksi.

d. Kelompok menjual hasil produksi secara perorangan

\section{Metode Analisis Data}

Analisis data yang digunakan dalam penelitian ini adalah secara deskriptif, yang disajikan dalam bentuk tabel. Data yang dihasilkan dianalisis dengan menggunakan Skala Likert dalam analisis ini dijelaskan peranan kelompok tani "Tenggang Rasa" berdasarkan Kelas Belajar, Wahana Kerja Sama dan Unit Produksi. Ketiga peranan tersebut dianalisis dalam bentuk tabel. Untuk mengetahui peran kelompok tani ada sebanyak 14 pertanyaan dengan total responden 15 orang. Setiap jawaban dihubungkan dengan kata-kata yaitu jenjang 1 (tidak pernah), 2 (kadangkadang), 3 (selalu). Dengan perhitungan skor masing-masing pertanyaan:

Jumlah skor tiap kriterium = capaian skor $\mathrm{x}$ jumlah responden

Untuk S3 $=3 \times 15=45$

$$
\begin{aligned}
& S 2=2 \times 15=30 \\
& S 1=1 \times 15=15
\end{aligned}
$$

Jumlah skor ideal untuk setiap pernyataan (skor tertinggi) $=45$

Jumlah skor terendah $=15$ dengan interpretasi nilai:

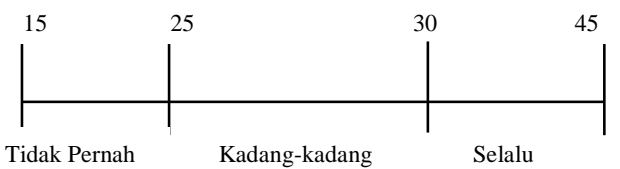

Cara perhitungan skor keseluruhan untuk mengetahui peranan kelompok tani "Tenggang Rasa" terhadap pengembangan tanaman kakao di Desa Inomunga. Jumlah skor seluruh kriterium $=$ Capaian jumlah skor $\mathrm{x}$ Jumlah Responden $\mathrm{x}$ Jumlah Pertanyaan

Untuk:

$\mathrm{S} 3=3 \times 15 \times 14=630$

$\mathrm{S} 2=2 \times 15 \times 14=420$

$\mathrm{S} 1=1 \times 15 \times 14=210$

Jumlah skor ideal untuk keseluruhan pertanyaan $=$ 630

Jumlah skor terendah $=210$

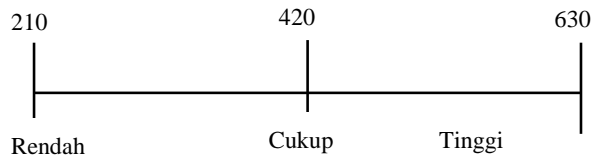

Analisis data yang digunakan merupakan analisis deskriptif yang diukur dengan skala likert menurut Ridwan (2012) disesuaikan dengan kasus adalah sebagai berikut:

Jumlah Skor Hasil Pengumpulan Data Tingkat Peranan Kelompok tani $=$ $\times 100 \%$ Jumlah Skor Ideal (tertinggi)

Dengan interpretasi nilai:

$$
210 \times 100 \%=33,33 \%
$$

$\overline{630}$

$420 \times 100 \%=66,66 \%$

$\overline{630}$

$630 \times 100 \%=100 \%$

$\overline{630}$

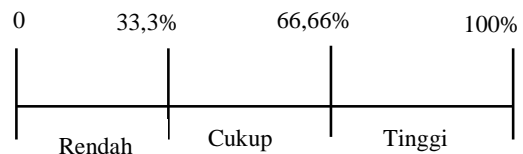

Keterangan kriteria interpretasi skor:

Angka $0-33,33 \%=$ Kategori Rendah

Angka $34 \%-66,66 \%=$ Kategori Cukup

Angka $67 \%-100 \%=$ Kategori Tinggi

\section{HASIL DAN PEMBAHASAN}

\section{Deskripsi Wilayah Penelitian}

\section{Sejarah Desa Inomunga}

Kata Inomunga berasal dari bahasa Kaidipang Besar yaitu nomunga yang berarti berbuah. Sedangkan, "I" itu kalimat seruan karena pada zaman Kerajaan Kaidipang Besar tepatnya pada masa kekuasaan raja Ramsis Ponto Inomunga di tetapkan sebagai wilayah perkebunan para bangsawan kerajaan yang mendiami Desa Boroko, yang berarti Peda. Jadi, orang-orang Boroko menyediakan Peda untuk berkebun di Desa Inomunga. Pada zaman dahulu orang-orang kerajaan biasanya sering memakan buah dan membuang bijinya begitu saja dan beberapa tahun kemudian biji-biji tersebut berbuah menjadi tanaman.

\section{Letak Geografis}

Desa Inomunga merupakan salah satu desa yang terletak di wilayah Bolaang Mongondow Utara Kecamatan Kaidipang Sulawesi Utara dengan batas-batas sebagai berikut : 
Sebelah Selatan dengan Desa Boroko Sebelah Utara dengan Desa Inomunga Utara Sebelah Timur dengan Desa Inomunga Sebelah Barat dengan Desa Komus 2

Pembagian wilayah di Desa Inomunga yaitu terdiri atas 3 (tiga) dusun atau jaga, dengan luas wilayah keseluruhan yaitu 1.297 Hektar.

\section{Keadaan Penduduk}

Total keseluruhan jumlah penduduk yang ada di Desa Inomunga sebanyak 758 jiwa, dengan jumlah KK adalah $111 \mathrm{KK}$.

\begin{tabular}{|c|c|c|c|}
\hline & $\begin{array}{l}\text { Kelamin } \\
2016\end{array}$ & i Desa & unga Tahur \\
\hline No & $\begin{array}{c}\text { Jenis } \\
\text { Kelamin }\end{array}$ & $\begin{array}{c}\text { Jumlah } \\
\text { (jiwa) }\end{array}$ & $\begin{array}{c}\text { Persentase } \\
(\%)\end{array}$ \\
\hline 1 & Laki-laki & 269 & 35 \\
\hline 2 & Perempuan & 489 & 65 \\
\hline & Total & 758 & 100 \\
\hline
\end{tabular}

Sumber: Kantor Desa Inomunga, 2016

Tabel 1 menunjukkan bahwa jumlah penduduk berjenis kelamin perempuan (65\%) lebih besar dari pada penduduk dengan jenis kelamin laki-laki (35\%). Jumlah penduduk menurut Tingkat Pendidikan di Desa Inomunga dapat dilihat pada Tabel 2 :

\begin{tabular}{|c|c|c|c|}
\hline Ta & $\begin{array}{l}\text { 2. Jumla } \\
\text { Tingka } \\
\text { Inomun }\end{array}$ & $\begin{array}{r}\text { Pendu } \\
\text { Pendidi } \\
\text { a Tahun }\end{array}$ & \begin{tabular}{ll} 
lk menurut & \multicolumn{2}{c}{ m di Desa } \\
16 &
\end{tabular} \\
\hline No & $\begin{array}{c}\text { Tingkat } \\
\text { Pendidikan }\end{array}$ & Jumlah & $\begin{array}{c}\text { Persentase } \\
(\%)\end{array}$ \\
\hline 1 & $\begin{array}{l}\text { Belum } \\
\text { sekolah/Putus } \\
\text { Sekolah }\end{array}$ & 125 & 16,5 \\
\hline 2 & SD & 175 & 23,1 \\
\hline 3 & SMP & 230 & 30,3 \\
\hline 4 & SMA & 178 & 23,5 \\
\hline 5 & $\begin{array}{l}\text { Perguruan } \\
\text { Tinggi }\end{array}$ & 50 & 6,6 \\
\hline & Total & 758 & 100 \\
\hline
\end{tabular}

Sumber: Kantor Desa Inomunga, 2016

Dari Tabel 2 menunjukkan bahwa sebagian besar penduduk di Desa Inomunga belum memperoleh pendidikan yang cukup karena sebagian besar berpendidikan pada tingkat SD dengan presentase $23,1 \%$ dan tingkat SMP 30,3\%. Sedangkan untuk tingkat SMA 23,5\% dan Perguruan Tinggi hanya 6,6 $\%$. Tingkat pendidikan yang dimiliki akan sangat mempengaruhi dalam melaksanakan usahataninya. Penduduk di Desa Inomunga umumnya bermata pencaharian sebagai petani, ditunjukkan Tabel 3:

Tabel 3. Jumlah Penduduk menurut Pekerjaan di Desa Inomunga Tahun 2016

\begin{tabular}{llrc}
\multicolumn{2}{c}{$\mathbf{2 0 1 6}$} & & \\
\hline No & $\begin{array}{c}\text { Mata } \\
\text { Pencaharian }\end{array}$ & Jumlah & Persentase (\%) \\
1 & PNS & 50 & 6,6 \\
2 & Petani & 253 & 33,4 \\
3 & Nelayan & 150 & 19,8 \\
4 & Wiraswasta & 55 & 7,2 \\
5 & Buruh & 150 & 19,8 \\
6 & Tidak/belum & 100 & 13,2 \\
& bekerja & & \\
\hline & Total & 758 & 100 \\
\hline
\end{tabular}

Sumber: Kantor Desa Inomunga, 2016

Tabel 3 menunjukkan bahwa sebagian besar penduduk di Desa Inomunga bermata pencaharian sebagai petani dengan jumlah 253 orang atau sebesar $33,4 \%$, hal ini menunjukkan bahwa perekonomian masih bersifat agraris yang di tunjukkan oleh banyaknya penduduk bekerja pada sektor pertanian.

\section{Deskripsi Kelompok Tani “Tenggang Rasa"}

\section{Sejarah Kelompok Tani “ Tenggang Rasa”}

Pada awal mulanya sebelum kelompok tani diberi nama sebagai kelompok tani Tenggang Rasa, kelompok ini memiliki nama "Pomomuntula" dan masih bergabung dengan Desa Boroko dengan beberapa komoditi usaha perkebunan, pertanian, pangan, dan hortikultura. Kelompok tani "Tenggang Rasa" berdiri pada hari Sabtu, tanggal 14 Februari 2011 dengan Komoditi yang berbeda. Setelah Program Gernas masuk ke Bolmut pada tahun 2012, maka BP4K dan petugas pendamping membentuk kelompok tani ini untuk bekerja sebagai petani kakao dengan Program Gernas. Atas usul dari petugas pendamping program Gernas maka kelompok ini mengganti nama 
sebagai kelompok tani "Tenggang Rasa" dengan arti bahwa setiap anggota dapat saling membantu dan gotong royong. Kelompok tani ini bukan lagi berada di Desa Boroko tetapi sudah berdiri di Desa Inomunga dengan satu komoditi perkebunan yaitu kakao dengan mengelola lahan masing-masing anggota sampai sekarang.

\section{Karakteristik Responden}

\section{Umur Responden}

Kemampuan bekerja atau melakukan aktivitas secara fisik bahkan cara berpikir seseorang sangat dipengaruhi faktor umur. Demikian juga dengan para petani dalam melakukan pekerjaannya, anggota yang memiliki umur muda cara berpikirnya lebih kreatif dan kondisi fisik lebih kuat dari umur yang lebih tua. Dari 15 petani responden yang di ambil di Desa Inomunga berdasarkan kelompok umur dapat dilihat pada Tabel 4.

Tabel 4. Jumlah Anggota Kelompok Tani "6 Tenggang Rasa” berdasarkan Kelompok Umur di Desa Inomunga

\begin{tabular}{cccc}
\hline No & $\begin{array}{c}\text { Kelompok } \\
\text { Umur }\end{array}$ & Jumlah & Persentase (\%) \\
1 & $27-31$ & 1 & 7 \\
2 & $32-36$ & 4 & 27 \\
3 & $37-41$ & 1 & 7 \\
4 & $42-46$ & 3 & 20 \\
5 & $47-51$ & 3 & 20 \\
6 & $52-56$ & - & - \\
7 & $57-61$ & - & - \\
8 & $62-66$ & 2 & 13 \\
9 & $\geq 67$ & 1 & 100 \\
\hline & Jumlah & 15 &
\end{tabular}

Sumber: Diolah dari data primer, 2016

Tabel 4 menunjukkan bahwa sebagian besar responden berada pada kategori umur produktif, dengan kisaran terbesar yaitu 32-36 tahun dengan persentase $27 \%$ dengan jumlah 4 responden. Diikuti oleh kisaran umur 42-46 tahun dan umur 47-51 tahun dengan persentase dan jumlah responden yang sama yaitu $20 \%$ dan 3 responden. Kisaran umur 62-66 tahun dengan jumlah responden 2 orang dengan persentase 13 $\%$, sedangkan kisaran umur 27-31 tahun dan umur 37-41 tahun memiliki jumlah reponden dan persentase yang sama hanya $7 \%$ dengan jumlah 1 responden. Pada Tabel 4 dapat dilihat pula bahwa yang berumur di atas usia produktif yaitu kisaran umur lebih besar dari 67 tahun hanya 1 responden. Hal ini menunjukkan bahwa di Desa Inomunga masih ada petani yang usia sudah tidak produktif lagi.

\section{Tingkat Pendidikan Responden}

Pendidikan sangat penting dalam usaha peningkatan kualitas seseorang karena berguna dalam pembangunan pribadi serta peningkatan intelektual dan wawasan seseorang. Tabel 5 menunjukkan tingkat pendidikan anggota kelompok tani "Tenggang Rasa"

Tabel 5. Anggota Kelompok Tani "Tenggang Rasa" berdasarkan Pendidikan di Desa Inomunga

\begin{tabular}{llcc}
\hline No & $\begin{array}{c}\text { Tingkat } \\
\text { Pendidikan }\end{array}$ & Jumlah & Persentase (\%) \\
1 & S1 & 4 & 27 \\
2 & SMA & 3 & 20 \\
3 & SMP & 4 & 27 \\
4 & SD & 3 & 20 \\
5 & TS & 1 & 7 \\
\hline & Jumlah & 15 & 100 \\
\hline
\end{tabular}

Sumber: Diolah dari data primer, 2016

Dari Tabel 5 dapat dilihat bahwa responden memiliki pendidikan formal, dengan tingkat pendidikan terbanyak adalah Sarjana dengan jumlah reponden 4 orang $(27 \%)$. Di tingkat SMA memililki 20\% dengan jumlah 3 reponden. Sedangkan di tingkat SMP sama dengan Sarjana yaitu jumlah responden sebanyak 4 orang (27\%). Di tingkat SD sebanyak 3 responden dengan (20\%), sedangkan jumlah responden yang tidak sekolah hanya 1 orang atau persentase $7 \%$.

\section{Peranan Kelompok Tani terhadap Pengembangan Tanaman Kakao di Desa Inomunga}

\section{Peranan Kelompok Tani sebagai Kelas Belajar}

1. Peran Kelompok Tani dalam tukar menukar pikiran

Peranan kelompok dalam kelas belajar dapat dilihat melalui peran kelompok dalam tukar menukar pikiran. Dengan saling tukar 
menukar pikiran baik anggota maupun pengurus dapat membantu kegiatan organisasi. Untuk peran kelompok dapat dilihat pada Tabel 6.

Tabel 6. Peran Kelompok Tani dalam Tukar Menukar Pikiran

\begin{tabular}{clcccc}
\hline No & $\begin{array}{l}\text { Alternatif } \\
\text { Jawaban }\end{array}$ & Skor & $\begin{array}{c}\text { Jumlah } \\
\text { Responden }\end{array}$ & $\%$ & $\begin{array}{c}\text { Total } \\
\text { skor }\end{array}$ \\
1 & Selalu & 3 & 11 & 73 & 33 \\
2 & $\begin{array}{l}\text { Kadang- } \\
\text { kadang }\end{array}$ & 2 & 3 & 20 & 6 \\
3 & $\begin{array}{l}\text { Tidak } \\
\text { pernah }\end{array}$ & 1 & 1 & 7 & 1 \\
\hline & Total & & 15 & 10 & 40 \\
& & & & 0 & \\
\hline
\end{tabular}

Catatan: Dalam Pertemuan 1 tahun (2016)

Hasil penelitian menunjukkan bahwa $73 \%$ (11 orang) dengan menjawab selalu hal ini karena anggota melakukan perannya dalam tukar menukar pikiran dalam upaya pengembangan kakao. Hal ini dilakukan agar supaya kelompok dapat dengan mudah mengatasi masalah-masalah yang terjadi. Dengan saling tukar pikiran dapat melaksanakan tujuan bersama. Sedangkan, 20\% (3 orang) menjawab kadangkadang karena anggota tidak selalu hadir dalam setiap pertemuan yang dilakukan oleh ketua Kelompok tani. Anggota Kelompok tani tidak pernah melakukan tukar menukar pikiran sebesar 7\% (1 orang) karena mempunyai pekerjaan yang lain sehingga dia tidak dapat menghadiri pertemuan. Dengan total skor yang diperoleh dari 15 responden pada indikator pernyataan 1 yaitu sebesar 40 . Angka indeks pada pernyataan 1 yaitu $40 / 45 \times 100=88,88 \%$ sehingga interpretasi nilainya kategori tinggi karena kelompok tani selalu melakukan tukar menukar pikiran baik anggota maupun pengurus kelompok. Anggota yang berada dalam kelompok tani saling tukar-menukar informasi, dan dengan adanya kelancaran arus informasi semakin tinggi kepuasan anggota, berarti dinamika kelompok semakin baik. Biasanya anggota kelompok saling menjelaskan sesuatu kepada anggota apabila ada hal-hal yang kurang jelas seperti anggota yang lebih berpengalaman akan menjelaskan kepada anggota yang lain yang belum mengetahuinya. Biasanya informasi tentang kegiatan pemberantasan atau pengendalian hama dan penyakit secara terpadu, berusaha memperbaiki prasarana-prasarana yang menunjang usahataninya.

2.Pelaksanaan Penyuluhan untuk pengembangan tanaman kakao.

Penyuluhan yang dilakukan Penyuluh dan Petugas Pendamping Kakao untuk pengembangan tanaman kakao ditunjukkan pada Tabel 7

Tabel 7. Pelaksanaan Penyuluhan dilakukan Penyuluh dan Petugas Pendamping

\begin{tabular}{clcccc}
\hline No & $\begin{array}{l}\text { Alternatif } \\
\text { Jawaban }\end{array}$ & Skor & $\begin{array}{c}\text { Jumlah } \\
\text { Responden }\end{array}$ & $\%$ & $\begin{array}{c}\text { Total } \\
\text { skor }\end{array}$ \\
1 & $\begin{array}{l}\text { Selalu } \\
2\end{array}$ & 3 & 10 & 67 & 30 \\
& $\begin{array}{l}\text { Kadang- } \\
\text { kadang }\end{array}$ & 2 & 5 & 33 & 10 \\
3 & $\begin{array}{l}\text { Tidak } \\
\text { pernah }\end{array}$ & 1 & 0 & 0 & 0 \\
\hline & Total & & 15 & 100 & 40 \\
\hline
\end{tabular}

Catatan: Dalam Pertemuan 1 tahun (2016)

Hasil penelitian menunjukkan bahwa 67\% (10 orang) menjawab Selalu, karena dengan adanya Penyuluh dan Pendamping petani dapat belajar. Biasanya yang dilakukan penyuluh yaitu memantapkan cara bertani dengan menyelenggarakan demonstrasi cara bercocok tanam, pembibitan dan cara mengatasi hama dan Petugas Pendamping yang langsung turun lapangan bersama dengan petani. Sedangkan, Kadang-kadang 33\% (5 orang) karena anggota kelompok ini jarang mengikuti pertemuan dengan Penyuluh dan Petugas Pendamping karena ada aktivitas lain. Dapat dilihat dengan total skor dari 15 responden pada indikator pernyataan 2 yaitu 40. Angka indeks pada pernyataan 2 yaitu $40 / 45 \times 100=88,88 \%$ dengan interpretasi nilainya Tinggi. Karena Penyuluh dan Pendamping selalu melakukan penyuluhan. 3. Ikut serta anggota kelompok dalam
penyuluhan

Peranan kelompok dalam kelas belajar adalah keikutsertaan anggota kelompok dalam penyuluhan yang dilakukan Penyuluh dan Pendamping Kakao. Dengan tujuan agar supaya kelompok dapat lebih mengetahui cara untuk pengembangan tanaman kakao. Hal ini ditunjukkan pada Tabel 8. 
Tabel 8. Ikut serta Anggota Kelompok dalam Penyuluhan

\begin{tabular}{clcccc}
\hline No & $\begin{array}{l}\text { Alternatif } \\
\text { Jawaban }\end{array}$ & Skor & $\begin{array}{c}\text { Jumlah } \\
\text { Responden }\end{array}$ & \% & $\begin{array}{c}\text { Total } \\
\text { skor }\end{array}$ \\
1 & $\begin{array}{l}\text { Selalu } \\
2\end{array}$ & 3 & 8 & 53 & 24 \\
$\begin{array}{l}\text { Kadang- } \\
\text { kadang } \\
\text { Tidak } \\
\text { pernah }\end{array}$ & 2 & 5 & 33 & 10 \\
\hline \multicolumn{2}{c}{ Total } & 1 & 2 & 13 & 2 \\
\hline
\end{tabular}

Hasil penelitian menunjukkan bahwa $53 \%$ (8 orang) selalu ikut serta dalam penyuluhan tersebut karena anggota dapat lebih mengetahui cara pemeliharaan/perawatan tanaman Kakao dan dapat mengatasi masalah Hama/Penyakit tanpa bantuan dari Pendamping Kakao, dan $33 \%$ (5 orang) kadang-kadang mengikuti penyuluhan karena mereka sudah banyak mengetahui cara-cara Pengolahan tanaman Kakao dan ada kegiatan lain sehingga mereka tidak hadir. Tidak pernah mengikuti penyuluhan adalah 13\% (2 orang) biasanya anggota kelompok yang tidak mengikuti penyuluhan adalah mereka yang sudah berpengalaman dan banyak mengetahui cara-cara pengolahan tanaman kakao sehingga pada waktu diadakan penyuluhan mereka sudah tidak ikut lagi. Dapat dilihat dengan total skor dari 15 responden pada indikator pernyataan 3 yaitu 36. Angka indeks pada pernyataan 3 yaitu $36 / 45 \times 100=80 \%$ dengan interpretasi nilainya kategori tinggi karena anggota kelompok tani selalu mengikuti penyuluhan.

\section{Kelompok mempraktekkan hasil penyuluhan} yang dilakukan

Peranan kelompok dalam kelas belajar adalah apakah kelompok langsung mempratekkan materi yang dilakukan penyuluh untuk pengembangan tanaman kakao ditunjukkan pada Tabel 9.

\begin{tabular}{|c|c|c|c|c|c|}
\hline Tabe & $\begin{array}{c}\text { 9. Ke } \\
\text { Peny }\end{array}$ & $\begin{array}{l}\text { mpok } \\
\text { luhan }\end{array}$ & $\begin{array}{l}\text { Memprakt } \\
\text { ang di lakuk }\end{array}$ & & Hasil \\
\hline No & $\begin{array}{c}\text { Alternatif } \\
\text { Jawaban }\end{array}$ & Skor & $\begin{array}{c}\text { Jumlah } \\
\text { Responden }\end{array}$ & $\%$ & $\begin{array}{l}\text { Total } \\
\text { skor }\end{array}$ \\
\hline 1 & Selalu & 3 & 6 & 40 & 18 \\
\hline 2 & $\begin{array}{l}\text { Kadang- } \\
\text { kadang }\end{array}$ & 2 & 9 & 60 & 18 \\
\hline 3 & $\begin{array}{l}\text { Tidak } \\
\text { pernah }\end{array}$ & 1 & 0 & 0 & 0 \\
\hline & Total & & 15 & 100 & 36 \\
\hline
\end{tabular}

Dari hasil penelitian menunjukkan bahwa 60\% anggota kelompok tani masih jarang (kadang-kadang) mempraktekkan apa yang disampaikan oleh penyuluh karena anggota kelompok tani kurang memahami materi yang di sampaikan oleh penyuluh mereka lebih memahami jika dipraktekkan secara langsung oleh pendamping kakao. Sedangkan, $40 \%$ anggota kelompok tani langsung mempraktekkannya karena responden merupakan pengurus kelompok tani agar supaya mereka dapat memberikan contoh kepada anggota kelompok. Hal ini ditunjukkan dengan total skor dari 15 responden pada indikator pernyataan 4 yaitu 36. Angka indeks pada pernyataan 3 yaitu $36 / 45 \times 100=80 \%$ dengan interpretasi nilainya kategori tinggi. Hanya 2 anggota selisih antara selalu dan kadang-kadang mempraktekkan materi yang disampaikan oleh penyuluh. sehingga dapat disimpulkan bahwa anggota kelompok tani "Tenggang Rasa" langsung mempraktekkan materi yang disampaikan oleh penyuluh.

\section{Peran Kelompok Tani "Tenggang Rasa" sebagai Wahana Kerjasama}

1. Kelompok bersama-sama mengatasi masalah yang terjadi dalam penanggulangan hama dan penyakit pada kakao

Dari pernyataan ini yang dilihat apakah kelompok bersama-sama mengatasi masalah yang terjadi dalam penanggulangan hama dan penyakit pada kakao. Untuk mengatasi masalahmasalah yang terjadi baik pada kelompok maupun masalah yang terjadi pada tanaman kakao butuh kerjasama dari kelompok agar supaya dapat diselasaikan dengan baik masalah yang terjadi. (Tabel 10).

Tabel 10. Kelompok Bersama-sama Mengatasi Masalah yang terjadi dalam Penanggulangan hama dan penyakit pada Kakao

\begin{tabular}{clcccc}
\hline No & $\begin{array}{l}\text { Alternatif } \\
\text { Jawaban }\end{array}$ & Skor & $\begin{array}{c}\text { Jumlah } \\
\text { Responden }\end{array}$ & $\%$ & $\begin{array}{c}\text { Total } \\
\text { skor }\end{array}$ \\
1 & $\begin{array}{l}\text { Selalu } \\
2\end{array}$ & 3 & 10 & 67 & 30 \\
& $\begin{array}{l}\text { Kadang- } \\
\text { kadang }\end{array}$ & 2 & 4 & 26 & 8 \\
3 & $\begin{array}{l}\text { Tidak } \\
\text { pernah }\end{array}$ & 1 & 1 & 7 & 1 \\
\hline \multicolumn{2}{r}{ Total } & & 15 & 100 & 39 \\
\hline
\end{tabular}


Hasil penelitian menunjukkan bahwa 67\% kelompok melakukan kerjasama dalam mengatasi masalah yang terjadi pada penanggulangan hama dan penyakit pada kakao karena dengan bersama-sama akan lebih mudah anggota mengatasi masalah yang terjadi pada tanaman kakako. Sedangkan, 26\% menjawab masih jarang atau kadang-kadang melakukan kerjasama karena anggota kelompok lain hanya berharap pada Pendamping dalam mengatasi masalah pada tanaman Kakao. Dan 7\% yang tidak pernah melakukan kerjasama karena anggota sudah mempercayakan penuh kepada Pendamping Kakao. Dengan total skor yang diperoleh dari 15 responden pada indikator pernyataan 5 yaitu sebesar 39. Angka indeks pada pernyataan 5 yaitu $39 / 45 \times 100=86,66 \%$ sehingga interpretasi nilainya kategori tinggi karena kelompok tani ini selalu melakukan kerjasama atau selalu mengatasi masalah yang terjadi pada tanaman kakao secara bersama-sama. Dalam penanggulangan hama dan penyakit tanaman kakao ini biasanya petani di kelompok ini melaksanakan pengadaan bibit yang resisten untuk memenuhi kepentingan para anggotanya termasuk pengadaan sarana produksi murah dengan cara melakukan pembelian secara bersama-sama pula.

\section{Anggota Kelompok berkoordinasi dengan Pengurus Kelompok}

Peranan kelompok dalam wahana kerjasama dapat dilihat melalui peran anggota kelompok dalam berkoordinasi dengan pengurus kelompok. Dengan saling berkoordinasi antara anggota maupun pengurus, maka kelompok dapat melakukan kerjasama yang baik guna untuk mempermudah dalam mengorganisasi serta dapat mencapai tujuan bersama. Untuk peran kelompok dapat dilihat pada Tabel 11.

Tabel 11. Anggota Kelompok Berkoordinasi dengan Pengurus Kelompok

\begin{tabular}{clcccc}
\hline No & $\begin{array}{l}\text { Alternatif } \\
\text { Jawaban }\end{array}$ & Skor & $\begin{array}{c}\text { Jumlah } \\
\text { Responden }\end{array}$ & $\%$ & $\begin{array}{c}\text { Total } \\
\text { skor }\end{array}$ \\
1 & $\begin{array}{l}\text { Selalu } \\
2\end{array}$ & 3 & 10 & 67 & 30 \\
Kadang- & 2 & 5 & 33 & 10 \\
& $\begin{array}{l}\text { kadang } \\
\text { Tidak } \\
\text { pernah }\end{array}$ & 1 & 0 & 0 & 0 \\
\hline & Total & & 15 & 100 & 40 \\
\hline
\end{tabular}

Tabel 11 menunjukkan bahwa $67 \%$ anggota kelompok tani selalu berkoordinasi dengan pengurus karena dengan adanya hubungan kerjasama yang baik dengan pengurus maka suatu organisasi akan berjalan dengan lancar, sedangkan 33\% menunjukkan bahwa anggota jarang atau kadang-kadang berkoordinasi dengan pengurus karena anggota langung berhubungan dengan Pendamping Kakao. Total skor yang diperoleh dari 15 responden pada indikator pernyataan 6 yaitu sebesar 40. Angka indeks pada pernyataan 6 yaitu $40 / 45 \times 100=88,88 \%$ sehingga interpretasi nilainya kategori tinggi sehingga dapat disimpulkan bahwa anggota kelompok tani selalu berkoordinasi dengan pengurus untuk pengembangan tanaman kakao.

3. Kelompok Melakukan Kerjasama antar Anggota Kelompok dengan Kelompok Tani yang lain

Tabel 12 menunjukkan Kelompok Tani "Tenggang Rasa" melakukan kerjasama untuk pengembangan tanaman kakao baik antar anggota kelompok ataupun dengan kelompok tani yang lain.

Tabel 12. Kelompok Melakukan Kerja sama Antar Anggota Kelompok dengan kelompok tani yang lain

\begin{tabular}{clcccc}
\hline No & $\begin{array}{l}\text { Alternatif } \\
\text { Jawaban }\end{array}$ & Skor & $\begin{array}{c}\text { Jumlah } \\
\text { Responden }\end{array}$ & $\%$ & $\begin{array}{c}\text { Total } \\
\text { skor }\end{array}$ \\
1 & $\begin{array}{l}\text { Selalu } \\
2\end{array}$ & 3 & 6 & 40 & 18 \\
& $\begin{array}{l}\text { Kadang- } \\
\text { kadang }\end{array}$ & 2 & 7 & 47 & 14 \\
3 & $\begin{array}{l}\text { Tidak } \\
\text { pernah }\end{array}$ & 1 & 2 & 13 & 2 \\
\hline & Total & & 15 & 100 & 34 \\
\hline
\end{tabular}

Hasil penelitian menunjukkan bahwa 47\% kelompok tani “Tenggang Rasa" jarang atau kadang-kadang melakukan kerjasama baik antar anggota maupun antar kelompok tani yang lain karena anggota langsung berkoordinasi dengan pendamping kakao. Sedangkan, 40\% selalu melakukan kerjasama baik anggota dengan anggota kelompok tani lain untuk agar supaya lebih mudah dalam mengatasi masalah yang terjadi pada tanaman kakao dan yang selalu berkoordinasi merupakan pengurus kelompok tani. Dan 13\% tidak pernah melakukan kerjasama antar anggota maupun kelompok tani yang lain 
karena anggota tidak memiliki waktu dan kesempatan melakukan pertemuan dengan alasan ada kegiatan lain yang dilakukan. Dengan total skor yang diperoleh dari 15 responden pada indikator pernyataan 7 yaitu sebesar 34. Angka indeks pada pernyataan 6 yaitu 34/45×100 = $75,55 \%$ sehingga interpretasi nilainya kategori tinggi dan dapat disimpulkan bahwa anggota kelompok tani selalu melakukan kerjasama baik anggota maupun dengan kelompok tani yang lain.

4. Kelompok melakukan pertemuan berkala untuk membahas pengembangan tanaman kakao terkait teknologi maupun sarana produksi.

Dari pernyataan ini dilihat apakah Kelompok tani "Tenggang Rasa" melakukan pertemuan berkala untuk membahas pengembangan tanaman kakao terkait dengan teknologi maupun sarana produksi (Tabel 13).

Tabel 13. Kelompok Melakukan Pertemuan Berkala Membahas Pengembangan Tanaman Kakao terkait Teknologi maupun Sarana Produksi

\begin{tabular}{clcccc}
\hline No & $\begin{array}{l}\text { Alternatif } \\
\text { Jawaban }\end{array}$ & Skor & $\begin{array}{c}\text { Jumlah } \\
\text { Responden }\end{array}$ & $\%$ & $\begin{array}{c}\text { Total } \\
\text { skor }\end{array}$ \\
1 & $\begin{array}{l}\text { Selalu } \\
2\end{array}$ & 3 & 7 & 47 & 21 \\
$\begin{array}{l}\text { Kadang- } \\
\text { kadang } \\
\text { Tidak } \\
\text { pernah }\end{array}$ & 2 & 8 & 53 & 16 \\
\hline & 1 & 0 & 0 & 0 \\
\hline & Total & & 15 & 100 & 37 \\
\hline
\end{tabular}

Dari hasil penelitian menunjukkan bahwa $47 \%$ (7orang) kelompok melakukan pertemuan berkala untuk membahas pengembangan tanaman kakao alasannya karena dengan melakukan pertemuan berkala akan lebih mudah dan akan semakin berkembang organisasinya baik Teknologi maupun sarana produksi pada kelompok tani. Sedangkan, yang jarang atau kadang-kadang melakukan pertemuan sebanyak 53\% alasan anggota mereka hadir apabila mereka tidak ada kegiatan lain atau ada aktivitas lain. Dengan total skor yang diperoleh dari 15 responden pada indikator pernyataan 7 yaitu sebesar 37. Angka indeks pada pernyataan 8 yaitu $37 / 45 \times 100=82,22 \%$ sehingga interpretasi nilai kategori tinggi dan dapat disimpulkan bahwa anggota kelompok tani "Tenggang Rasa" berperan dalam pertemuan berkala untuk membahas pengembangan tanaman kakao. Hal ini ditunjukkan pula dengan jadwal pertemuan sesuai dengan laporan dari pendamping tanaman kakao dalam kegiatan pertemuan selama tahun 2016 Tabel 14 menunjukkan kegiatan pendamping dalam mendampingi kelompok tani Tenggang Rasa. Pada pertemuan kelompok ini membahas tentang program dari kegiatan pengembangan kakao beserta teknik-teknik dan budidaya tanaman kakao. Karena mulai aktif pada tahun 2012 sampai dengan sekarang sehingga kelompok tani ini sudah tergolong dalam kelas lanjut dan kelompok tani Tenggang Rasa merupakan salah satu kelompok tani yang aktif di desa Innomunga.

5. Kelompok Mengadakan Pertemuan Membahas Tujuan Kelompok dan Anggaran Dasar/Anggaran Dasar Rumah Tangga

Dari pernyataan ini dilihat apakah kelompok mengadakan pertemuan untuk membahas tujuan kelompok dan Anggaran Dasar/Anggaran Dasar Rumah Tangga (Tabel 14).

Tabel 14. Kelompok Mengadakan Pertemuan Membahas Tujuan Kelompok dan Anggaran Dasar/Anggaran Dasar Rumah Tangga

\begin{tabular}{clcccc}
\hline No & $\begin{array}{l}\text { Alternatif } \\
\text { Jawaban }\end{array}$ & Skor & $\begin{array}{c}\text { Jumlah } \\
\text { Responden }\end{array}$ & $\%$ & $\begin{array}{c}\text { Tota } \\
\text { l } \\
\text { skor }\end{array}$ \\
1 & $\begin{array}{l}\text { Selalu } \\
2\end{array}$ & 3 & 5 & 33 & 15 \\
& $\begin{array}{l}\text { Kadang- } \\
\text { kadang }\end{array}$ & 2 & 8 & 54 & 16 \\
3 & $\begin{array}{l}\text { Tidak } \\
\text { pernah }\end{array}$ & 1 & 2 & 13 & 2 \\
\hline \multicolumn{2}{r}{ Total } & & 15 & 100 & 33 \\
\hline
\end{tabular}

Hasil penelitian menunjukkan bahwa 53\% anggota kelompok jarang atau kadangkadang mengadakan pertemuan untuk membahas tujuan kelompok dan Anggaran Dasar/Anggaran Dasar Rumah Tangga, sedangkan yang selalu mengikuti pertemuan hanya 33\%. Anggota yang tidak pernah mengikuti pertemuan sejumlah $13 \%$. Dengan total skor yang diperoleh dari 15 responden pada indikator pernyataan 8 yaitu sebesar 33. Angka indeks pada pernyataan 9 yaitu $33 / 45 \times 100=73,33 \%$ sehingga interpretasi nilainya tergolong kategori tinggi dan dapat disimpulkan bahwa anggota Kelompok tani "Tenggang rasa" berperan dalam pertemuan untuk membahas tujuan kelompok dan anggaran dasar/ anggaran dasar rumah tangga. Pada kenyaataan di lapangan belum semua 
anggota yang tergabung dalam kelopmok tani dapat mengikutinya dikarenakan sulitnya untuk mengadakan pertemuan di kelompok tani masingmasing ini disebabkan karena kesibukan yang berbeda-beda juga akses lokasi kebun yang jauh yang pada kenyataannya sangat menghalangi anggota untuk aktif dalam kelompok. Hal ini juga membedakan banyaknya pertemuan yang dilakukan pendamping kakao pada masingmasing kelompok tani. Jenis program kegiatan yang diberikan pada masing-masing anggota kelompok tani pada dasarnya adalah sama, akan tetapi yang membedakan adalah jumlah dan waktu kegiatan yang diikuti oleh anggota kelompok tani.

6. Kelompok Melakukan Pembagian Tugas berdasarkan Penetapan Kegiatan antar Anggota maupun dengan Pihak lain.

Tabel 15 menunjukkan kelompok melakukan pembagian tugas berdasarkan penetapan kegiatan yang akan dikerjasamakan baik antar anggota maupun dengan pihak lain.

\begin{tabular}{|c|c|c|c|c|c|}
\hline $\mathbf{T a}$ & $\begin{array}{l}\text { 15. Kelomp } \\
\text { Berdasar } \\
\text { Anggota } \\
\end{array}$ & $\begin{array}{r}\text { Me } \\
1 \quad P \\
\text { upur }\end{array}$ & $\begin{array}{l}\text { ukan Pem } \\
\text { etapan Ke } \\
\text { engan Piha }\end{array}$ & $\begin{array}{l}\text { latan } \\
\text { lain }\end{array}$ & $\begin{array}{c}\text { Tugas } \\
\text { antar }\end{array}$ \\
\hline No & $\begin{array}{c}\text { Alternatif } \\
\text { Jawaban }\end{array}$ & $\begin{array}{c}\text { Sko } \\
\text { r }\end{array}$ & $\begin{array}{c}\text { Jumlah } \\
\text { Responde } \\
\text { n }\end{array}$ & $\%$ & $\begin{array}{c}\text { Tota } \\
1 \\
\text { skor }\end{array}$ \\
\hline 1 & Selalu & 3 & 7 & 47 & 21 \\
\hline 2 & $\begin{array}{l}\text { Kadang- } \\
\text { kadang }\end{array}$ & 2 & 6 & 40 & 12 \\
\hline 3 & Tidak pernah & 1 & 2 & 13 & 2 \\
\hline & Total & & 15 & 100 & 35 \\
\hline
\end{tabular}

Hasil penelitian pada Tabel 15 menunjukkan bahwa 47\% kelompok melakukan pembagian tugas berdasarkan penetapan kegiatan yang akan dikerjasamakan baik antar anggota maupun dengan pihak lain karena dengan melaksanakan tugas dan menetapkan tugas masing-masing mempermudah anggota dalam beroraganisasi dan supaya kelompok dapat berjalan dengan baik dan terarah. Sedangkan yang jarang atau kadang-kadang adalah $40 \%$ karena anggota hanya berharap kepada pengurus kelompok untuk melaksanakan tugas . Tidak pernah melakukan pembagian tugas berdasarkan penetapan kegiatan yang dikerjasamakan baik antar anggota maupun dengan pihak lain 13\% karena anggota kelompok sudah tergolong lanjut usia. Total skor yang diperoleh dari 15 responden pada indikator pernyataan 10 yaitu sebesar 35 . Angka indeks pada pernyataan yaitu $35 / 45 \times 100=$ $77,77 \%$ sehingga interpretasi nilainya dalam kategori tinggi dan dapat disimpulkan bahwa anggota kelompok tani 'Tenggang Rasa' berperan dalam melakukan pembagian tugas berdasarkan penetapan kegiatan yang akan dikerjasamakan baik antar anggota maupun dengan pihak lain.

\section{Peran Kelompok Tani "Tenggang Rasa" sebagai Unit Produksi}

1. Kelompok Melakukan Kegiatan Melaksanakan Survei Identifikasi Kebutuhan Pasar

Kelompok tani sebagai unit produksi harus mampu memperkuat, memperlancar dan sekaligus mendorong pengembangan produksi yang menguntungkan. Salah satu peran kelompok sebagai unit produksi adalah melaksanakan Survei Identifikasi Kebutuhan Pasar.

Tabel 16. Kelompok Melakukan Kegiatan Melaksanakan Survei Identifikasi Kebutuhan Pasar

\begin{tabular}{clcccc}
\hline No & $\begin{array}{l}\text { Alternatif } \\
\text { Jawaban }\end{array}$ & Skor & $\begin{array}{c}\text { Jumlah } \\
\text { Responden }\end{array}$ & $\%$ & $\begin{array}{c}\text { Total } \\
\text { skor }\end{array}$ \\
1 & $\begin{array}{l}\text { Selalu } \\
2\end{array}$ & 3 & 6 & 40 & 18 \\
& $\begin{array}{l}\text { Kadang- } \\
\text { kadang } \\
\text { Tidak } \\
\text { pernah }\end{array}$ & 2 & 6 & 40 & 12 \\
& 1 & 3 & 20 & 3 \\
\hline & Total & & 15 & 100 & 33 \\
\hline
\end{tabular}

Tabel 16 menunjukkan bahwa petani yang menjawab selalu dan jarang melakukan kegiatan seperti melaksanakan survei identifikasi kebutuhan pasar memiliki persentase yang sama yaitu $40 \%$ karena dengan dilakukannya Survei identifikasi maka petani dengan mudah mengetahui harga naik turunnya Kakao. Anggota kelompok tidak pernah melaksanakan hanya $20 \%$ karena mereka langsung menjual kepada Tengkulak dan berapa pun harga yang ditentukan Tengkulak mereka tetap menjualnya. Dengan total skor yang diperoleh dari 15 responden pada indikator pernyataan 10 yaitu sebesar 33. Angka indeks pada pernyataan 11 yaitu $33 / 45 \times 100=73,33 \%$ sehingga interpretasi nilainya tergolong kategori tinggi dan dapat disimpulkan bahwa anggota kelompok tani "Tenggang Rasa" mempunyai peran dalam melakukan kegiatan seperti melaksanakan survei identifikasi kebutuhan pasar. 
2. Kelompok Menghitung Hasil/Jumlah Produski Kakao

Tabel 17 menunjukkan Kelompok Tani "Tenggang Rasa" menghitung hasil dan jumlah produksi kakao yang telah dihasilkan.

Tabel 17. Kelompok Menghitung Hasil/Jumlah Produski Kakao

\begin{tabular}{clcccc}
\hline No & $\begin{array}{l}\text { Alternatif } \\
\text { Jawaban }\end{array}$ & Skor & $\begin{array}{c}\text { Jumlah } \\
\text { Responden }\end{array}$ & $\%$ & $\begin{array}{c}\text { Total } \\
\text { skor }\end{array}$ \\
1 & $\begin{array}{l}\text { Selalu } \\
2\end{array}$ & 3 & 11 & 74 & 33 \\
& $\begin{array}{l}\text { Kadang- } \\
\text { kadang }\end{array}$ & 2 & 2 & 13 & 4 \\
3 & $\begin{array}{l}\text { Tidak } \\
\text { pernah }\end{array}$ & 1 & 2 & 13 & 2 \\
\hline \multicolumn{7}{r}{ Total } & & 15 & 100 & 39 \\
\hline
\end{tabular}

Dari hasil penelitian menunjukkan bahwa 74\% Kelompok Tani Tenggang Rasa selalu menghitung hasil dan jumlah produski kakao karena dengan menghitung jumlah produksi mereka dapat mengetahui pendapatan yang akan didapatkan oleh petani. Sedangkan yang kadangkadang dan tidak pernah menghitung produksi dan jumlah kakao memiliki persentase yang sama yaitu 13\%. Dengan total skor yang diperoleh dari 15 responden pada indikator pernyataan 12 yaitu sebesar 39. Angka indeks pada pernyataan yaitu $39 / 45 \times 100=86,66 \%$ sehingga interpretasi nilainya dalam kategori tinggi dan dapat disimpulkan bahwa Kelompok tani "Tenggang rasa mempunyai peran dalam melakukan kegiatan menghitung hasil/jumlah produski kakao.

\section{Peningkatan Produksi dan Lahan Produksi \\ Peningkatan produksi dan lahan} produksi tanaman kakao membutuhkan peranan dari petani sebagai anggota kelompok. Tabel 18 menunjukkan peranan kelompok dalam meningkatkan produksi dan lahan produksi kakao di Desa Inomunga.

Tabel 18. Peningkatan Produksi dan Lahan Produksi Kakao

\begin{tabular}{clcccc}
\hline No & $\begin{array}{l}\text { Alternatif } \\
\text { Jawaban }\end{array}$ & Skor & $\begin{array}{c}\text { Jumlah } \\
\text { Responden }\end{array}$ & $\%$ & $\begin{array}{c}\text { Total } \\
\text { skor }\end{array}$ \\
1 & Selalu & 3 & 8 & 53 & 24 \\
2 & $\begin{array}{l}\text { Kadang- } \\
\text { kadang }\end{array}$ & 2 & 7 & 47 & 14 \\
3 & $\begin{array}{l}\text { Tidak } \\
\text { pernah }\end{array}$ & 1 & & & \\
& & & & \\
\hline & Total & & 15 & 100 & 38 \\
\hline
\end{tabular}

Dari hasil penelitian menunjukkan 53\% mengatakan ada peningkatan produksi dan lahan produksi karena anggota aktif dalam pemeliharaan/perawatan tanaman kakao dan rajin mengikuti penyuluhan yang dilakukan penyuluh maupun pendamping dan langsung mempratekkannya sehingga tanaman kakao meningkat. Dan yang jarang atau kadangkadang 47\% hanya selisih 1 anggota dengan pernyataan selalu berarti yang jarang tetap ada peningkatan pada produksi walaupun tidak sebanding dengan selalu. Dengan total skor yang diperoleh dari 15 responden pada indikator pernyataan 13 yaitu sebesar 38. Angka indeks pada pernyataan yaitu $38 / 45 \times 100=84,44 \%$ sehingga interpretasi nilainya tergolong kategori tinggi dan dapat disimpulkan bahwa Kelompok tani" Tenggang Rasa mempunyai peran dalam peningkatan produksi dan lahan produksi kakao. Pengembangan tanaman Kakao dapat dilihat pada Peningkatan Produksi dan luas lahan pada tahun tanam 2007 dengan luas lahan $20 \mathrm{Ha}$ menunjukkan pada tahun 2014 Produksi Kakao sebesar 11800 Kg/tahun. Pada tahun 2015 terjadi penurunan.produksi. Jumlah Produksi pada tahun 2015 sebesar $9.222 \mathrm{~kg} /$ tahun dengan luas lahan yang sama. Hal ini di karenakan panas yang panjang. Sehingga, banyak tanaman Kakao yang mati dan buahnya pun berkurang. Cuaca yang tidak menentu yang menjadi kendala bagi Kelompok tani Kakao. Namun, Pada tahun 2016 terjadi peningkatan Produksi sebesar 13.400 $\mathrm{Kg} /$ Tahun dan luas lahan bertambah menjadi 22 Ha karena ada petani yang baru bergabung dalam Kelompok tani. Anggota Kelompok tani " Tenggang rasa" melakukan kerjasama dengan Pemerintah terkait serta Pendamping Kakao yang sangat berperan untuk meningkatkan Produksi Kakao. Pengembangan tanaman Kakao dapat dilihat dari peralatan dan perlengkapan Kelompok tani. Pada tahun 2011 Kelompok tani belum memiliki Peralatan. Namun, setelah pada tahun 2013 Pemerintah memberikan bantuan berupa gunting galah, mesin paras, gunting pangkas dan dibangunnya Gedung Fermentasi untuk tanaman Kakao. .

\section{Kelompok menjual Hasil Produksi secara Perorangan}

Hasil produksi merupakan hasil dari usaha petani sebagai anggota kelompok tani yang 
dijual secara perorangan. Tabel 20 menunjukkan anggota kelompok yang menjual hasil produksinya.

Tabel 19. Kelompok Menjual Hasil Produksi secara Perorangan

\begin{tabular}{clcccc}
\hline No & $\begin{array}{l}\text { Alternatif } \\
\text { Jawaban }\end{array}$ & Skor & $\begin{array}{c}\text { Jumlah } \\
\text { Responden }\end{array}$ & $\%$ & $\begin{array}{c}\text { Total } \\
\text { skor }\end{array}$ \\
1 & $\begin{array}{l}\text { Selalu } \\
2\end{array}$ & 3 & 12 & 80 & 36 \\
$\begin{array}{l}\text { Kadang- } \\
\text { kadang }\end{array}$ & 2 & 3 & 20 & 6 \\
3 & $\begin{array}{l}\text { Tidak } \\
\text { pernah }\end{array}$ & 1 & 0 & 0 & 0 \\
\hline \multicolumn{2}{r}{ Total } & 15 & 100 & 42 \\
\hline
\end{tabular}

Dari hasil penelitian menunjukkan $80 \%$ kelompok selalu menjual hasil produksi secara perorangan karena anggota mengolah lahan masing-masing dan belum ada mitra kerjasama antar kelompok dengan perusahaan sehingga produksi masih dijual pada tengkulak. Sedangkan, yang jarang atau kadang-kadang 20\% karena anggota menjual berkelompok karena masih merupakan anggota keluarga dan tidak memilki kendaraan sehingga untuk mengurangi biaya transport maka anggota menjual bersama. Dengan total skor yang diperoleh dari 15 responden pada indikator pernyataan 15 yaitu sebesar 42. Angka indeks pada pernyataan yaitu $42 / 45 \times 100=93,33 \%$ sehingga interpretasi nilainya tergolong dalam kategori tinggi dan dapat disimpulkan bahwa kelompok tani Tenggang Rasa berperan dalam menjual hasil produksi secara perorangan bukan berkelompok.

\section{Rekapitulasi Peranan Kelompok Tani Tenggang Rasa terhadap Pengembangan Tanaman Kakao Di Desa Inomunga.}

Hasil penelitian peranan kelompok tani Tenggang Rasa terhadap pengembangan tanaman kakao yang menggunakan 15 indikator sebagai tolak ukur dalam penelitian ini, dimana masing-masing terbagi dalam 3 (tiga) kategori yaitu kelas belajar, wahana kerjasama, dan unit produksi. Rekapitulasi hasil penelitian ditunjukkan dalam Tabel 20. Tabel 20 menunjukkan bahwa dari 14 indikator tentang peranan kelompok, indikator 1 sampai indikator 4 merupakan peran kelompok tani sebagai kelas belajar, mendapatkan skor pada indeks yang tergolong dalam kategori tinggi (67-100\%). Dari indikator 1-4 yang mendapatkan persentase dan jumlah responden tertinggi yaitu pada indikator 1 dan 2 dengan pernyataan kelompok tani selalu saling bertukar pikiran baik anggota dengan pengurus kelompok maupun dengan pihak lain dan Pernyataan Pelaksanaan penyuluhan yang dilakukan Penyuluh dan Pendamping untuk pengembangan tanaman kakao. Dengan total skor 40 dan persentase 88,88 . Sedangkan, skor yang tergolong rendah pada pernyataan kelompok melakukan pembagian tugas berdasarkan penetapan kegiatan yang dikerjasamakan baik antar anggota maupun dengan pihak lain. Dengan total skor hanya mendapatkan 33 dengan persentase sebesar $73,33 \%$. Pada indikator 5-10 merupakan peran kelompok tani sebagai wahana kerjasama, mendapatkan skor tergolong tinggi (67-100\%). Dari indikator 5-10 yang mendapatkan persentase dan total skor tertinggi yaitu pada indikator 5 dengan pernyataan anggota kelompok berkoordinasi dengan pengurus kelompok dengan total skor 40 dan persentase $88,88 \%$. Sedangkan, skor yang tergolong rendah pada pernyataan Kelompok mengadakan pertemuan untuk membahas tujuan kelompok dan Anggaran Dasar/Anggaran Dasar Rumah Tangga. Dengan total skor hanya mendapatkan 33 dengan persentase sebesar 77,77\%. Pada indikator 11-14 merupakan peran kelompok tani sebagai unit produksi, mendapatkan skor tergolong kategori tinggi (67-100\%). Dari indikator 11-14 yang mendapatkan persentase dan total skor tertinggi yaitu pada indikator 14 dengan pernyataan Kelompok menjual hasil produksi secara perorangan dengan total skor 42 dan persentase $93,33 \%$. Sedangkan, skor yang tergolong rendah dengan pernyataan Kelompok melakukan kegiatan seperti melaksanakan survei identifikasi kebutuhan pasar. Dengan total skor 33 dengan persentase $73,33 \%$. Untuk mengetahui peranan kelompok tani Tenggang Rasa terhadap pengembangan tanaman kakao di Desa Inomunga dihitung jumlah keseluruhan skor pada setiap kriterium, dan sesuai hasil 
penelitian skor mencapai 522. Dalam penelitian ini, jumlah skor ideal tertinggi 630 (kategori tinggi) dan jumlah skor terendah yaitu 225 (rendah). Berdasarkan data yang dihimpun dari 14 indikator pernyataan yang diajukan kepada 15 orang responden, diperoleh total skor 522. Secara persentase, angka indeks peranan kelompok tani Tenggang Rasa terhadap pengembangan tanaman kakao di Desa Inomunga sebagai berikut:

Jumlah Skor Hasil Pengumpulan Data

$\overline{\text { Peranan Kelompok Tani }=} \times 100 \%$
Jumlah Skor Ideal (tertinggi) = $\frac{522}{630} \times 100 \%=82,85 \%$

Berdasarkan hasil analisis menggunakan skala likert, indeks peranan kelompok tani Tenggang Rasa terhadap pengembangan tanaman kakao di Desa Inomunga berada pada titik 82,85\% dan tergolong dalam kategori tinggi. Hal ini berarti bahwa Kelompok Tani Tenggang Rasa mempunyai peranan dalam upaya pengembangan tanaman kakao di Desa Inomunga dalam hal peranan sebagai kelas belajar, wahana kerjasama maupun peranan dalam unit produksi.

Tabel 20. Rekapitulasi Total Skor, Indeks dan Interpretasi Hasil Penelitian

\begin{tabular}{|c|c|c|c|c|}
\hline No & $\begin{array}{c}\text { Peranan Kelompok Tani } \\
\text { Wahana Belaiar: }\end{array}$ & Total Skor & Indeks Peranan KT & Interprertasi \\
\hline 1. & $\begin{array}{l}\text { Peran kelompok tani dalam tukar menukar } \\
\text { pikiran }\end{array}$ & 40 & 88,88 & Tinggi \\
\hline 2. & $\begin{array}{l}\text { Pelaksanaan penyuluhan yang dilakukan } \\
\text { Penyuluh dan Pendamping untuk } \\
\text { pengembangan tanaman kakao. }\end{array}$ & 40 & 88,88 & Tinggi \\
\hline 3. & $\begin{array}{l}\text { Ikut serta anggota kelompok dalam } \\
\text { penyuluhan }\end{array}$ & 36 & 80 & Tinggi \\
\hline 4. & $\begin{array}{l}\text { Kelompok mempraktekkan hasil } \\
\text { penyuluhan yang dilakukan }\end{array}$ & 36 & 80 & Tinggi \\
\hline 5 & $\begin{array}{l}\text { Wahana Kerjasama: } \\
\text { Kelompok bersama-sama mengatasi } \\
\text { masalah yang terjadi dalam } \\
\text { penanggulangan hama dan penvakit }\end{array}$ & 39 & 86,66 & Tinggi \\
\hline 6. & $\begin{array}{l}\text { Kelompok berkoordinasi dengan pengurus } \\
\text { kelompok }\end{array}$ & 40 & 88,88 & Tinggi \\
\hline 7 & $\begin{array}{l}\text { Kelompok melakukan kerja sama untuk } \\
\text { pengembangan tanaman kakao baik antar } \\
\text { anggota kelompok atau dengan kelompok } \\
\text { tani yang lain. }\end{array}$ & 34 & 75,55 & Tinggi \\
\hline 8 & $\begin{array}{l}\text { Kelompok melakukan pertemuan berkala } \\
\text { untuk membahas pengembangan tanaman } \\
\text { kakao terkait dengan teknologi maupun } \\
\text { sarana produksi. }\end{array}$ & 37 & 82,22 & Tinggi \\
\hline 9 & $\begin{array}{l}\text { Kelompok mengadakan pertemuan untuk } \\
\text { membahas tujuan kelompok dan Anggaran } \\
\text { Dasar/Anggaran Dasar Rumah Tangga }\end{array}$ & 33 & 73,33 & Tinggi \\
\hline 10 & $\begin{array}{l}\text { Kelompok Melakukan Pembagian Tugas } \\
\text { Berdasarkan Penetapan Kegiatan antar } \\
\text { Anggota maupun dengan Pihak lain } \\
\text { Unit Produksi: }\end{array}$ & 35 & 77,77 & Tinggi \\
\hline 11 & $\begin{array}{l}\text { Kelompok melakukan kegiatan seperti } \\
\text { melaksanakan survei identifikasi } \\
\text { kebutuhan pasar }\end{array}$ & 33 & 73,33 & Tinggi \\
\hline 12. & $\begin{array}{l}\text { Kelompok menghitung hasil/jumlah } \\
\text { produski kakao }\end{array}$ & 39 & 86,66 & Tinggi \\
\hline 13. & $\begin{array}{l}\text { Peningkatan produksi dan lahan produksi } \\
\text { kakao }\end{array}$ & 38 & 84,44 & Tinggi \\
\hline 14. & $\begin{array}{l}\text { Kelompok menjual hasil produksi secara } \\
\text { perorangan }\end{array}$ & 42 & 93,33 & Tinggi \\
\hline
\end{tabular}




\section{KESIMPULAN DAN SARAN}

\section{Kesimpulan}

Kelompok tani "Tenggang Rasa" di Desa Inomunga Kecamatan Kaidipang mempunyai peranan terhadap pengembangan tanaman kakao di Desa Inomunga Kecamatan Kaidipang Kabupaten Bolaang Mongondow Utara. Peran kelompok sebagai kelas belajar tergolong dalam kategori tinggi karena kelompok berperan dalam tukar menukar pikiran, pelaksanaan penyuluhan, ikut serta dalam pelaksanaan penyuluhan, dan mempraktekkan hasil penyuluhan. Dengan adanya kelas belajar maka anggota dapat meningkatkan pengetahuan, keterampilan, sikap, serta dapat menumbuhkan kemandirian anggota dalam berusahatani. Kelompok Sebagai wahana kerjasama tergolong dalam kategori tinggi karena Kelompok berperan dalam mengatasi masalah yang terjadi dalam penanggulangan hama/penyakit, selalu berkoordinasi dengan pengurus kelompok, melakukan kerjasama antar anggota dengan kelompok tani lain, melakukan pertemuan berkala, mengikuti Penyuluhan yang dilakukan Penyuluh dan Pendamping hal ini berarti anggota saling mengenal, akrab, dan saling percaya serta mempunyai keinginan untuk berusahatani. Kelompok Sebagai Sebagai unit produksi tergolong dalam kategori tinggi karena berperan dalam melaksanakan survei pasar, peningkatan produksi dan lahan produksi. Hal ini berarti kelompok mampu meningkatkan pengembangan produksi pada tanaman kakao.

\section{Saran}

Saran dalam penelitian ini yaitu peranan kelompok tani "Tenggang Rasa" harus dipertahankan atau lebih ditingkatkan dalam melakukan perannya sebagai anggota kelompok baik dalam kelas belajar, wahana kerjasama, maupun dalam unit produksi.

\section{DAFTAR PUSTAKA}

Bustanul, A., 2015. Ekonomi Pembangunan Pertanian. PT Penerbit IPB Press, Bandung.
Hakam, A., 2014. Peran Kelompok Tani Terhadap Usaha Peningkatan Pendapatan Anggota melalui Program Kemitraan Usahatani, Vol. 27 (3), Malang.

Hermanto., 2011. Penguatan Kelompok Tani : Langkah Awal Peningkatan Kesejahteraan Petani. Analisis Kebijakan Pertanian Vol. 9 No. 4. Bogor.

Midiansyah E., 2011. Peranan Kelompok

Tani Dalam Mengembangkan

Kemandirian Petanidi Kabupaten

Tana Tidung,Vol. 35 No. 3.

Kalimantan Utara.

Iqbal M., 2014. Peranan Kelompok Tani dalam Meningkatkan Pendapatan Petani Padi Sawah Di Desa Margamulya. e-J. Agrotekbis Vol.2(5) : 505-509, Morowali.

Kementerian Pertanian No 51., 2012. Pedoman Teknis Penanganan Pascapanen Kakao.

Marru,D dan Sipayung, H., 2015. Kakao, Graha Ilmu, Yogyakarta.

Nuryanti, dan Swastika., 2011. Peran Kelompok Tani dalam Penerapan Teknologi Pertanian, Forum Penelitian Agro Ekonomi, Vol.29(2), Bogor.

Rahyunir, R dan Munaf, Y., 2015. Lembaga Kemasyarakatan di Indonesia. Zanafa Publishing, Yogyakarta.

Ridwan., 2012. Pengantar Statistika Sosial. Alfabeta. Bandung.

Rukmana, R., 2016. Agribisnis Kakao. Lily Publisher, Yogyakarta. 
Slamet, M., 2002. Kumpulan Bahan Kuliah : Kelompok, Organisasi dan Kepemimpinan (Tidak Dipublikasikan), IPB, Bogor.

Tuhana, A., 2014. Pengantar Ilmu Pertanian. Global Pustaka Utama, Yogyakarta.

Wuysang , R., 2015. Modal Sosial Kelompok Tani dalam Meningkatkan Pendapatan Keluarga Suatu Studi Dalam Pengembangan Usaha Kelompok Tani di Desa Tincep Kecamatan Sonder. Journal "Acta Diurna" Volume III. No.3, Manado.

Yuliandi., 2014. Strategi Pengembangan Usaha tani Kakao di Desa Sritaba'ang Kecamatan Bolano. e-J. Agrotekbis 2 (2) : 161-168, Palu. 